


\section{CLASSICS AND CONTEMPORARY THOUGHT}

Thomas Habinek, editor

I. Catullan Provocations: Lyric Poetry and the Drama of Position:, by William Fitzgerald

II. Reading Sappho: Contemporary Approaches, edited by Ellen Greene

III. Re-reading Sappho: Reception and Transmission, edited by Ellen Greene

IV. Tragedy and Enlightenment: Athenian Political Thought and the Dilemmas of Modernity, by Christopher Rocco

V. Warriors into Traders: The Power of the Market in Early Greece, by David W. Tandy 
Reading Sappho 



\title{
Reading Sappho
}

Contemporary Approaches

\author{
EDITED BY \\ Ellen Greene
}

UNIVERSITY OF CALIFORNIA PRESS

Berkeley Los Angeles London 


\author{
University of California Press \\ Berkeley and Los Angeles, California \\ University of California Press, Ltd. \\ London, England \\ (C) 1996 by \\ The Regents of the University of California
}

\title{
Library of Congress Cataloging-in-Publication Data
}

Reading Sappho : contemporary approaches / edited by Ellen Greene.

p. $\quad$ cm. - (Classics and contemporary thought : 2)

Includes bibliographical references and index.

ISBN 0-520-20195-7 (alk. paper) - ISBN 0-520-20601-o (pbk. : alk. paper)

I. Sappho-Criticism and interpretation. 2. Love poetry, Greek-History and criticism. 3. Women and literature-Greece. I. Greene, Ellen, 1950II. Series.

PA4409.R474 1996

$884^{\prime} \cdot$.or-dc2o

96-13702

CIP

Printed in the United States of America

$\begin{array}{lllllllll}9 & 8 & 7 & 6 & 5 & 4 & 3 & 2 & 1\end{array}$

The paper used in this publication meets the minimum requirements of American National Standard for Information Sciences-Permanence of Paper for Printed Library Materials, ANSI Z $39 \cdot 4$ 8-1984. 
To my father and to the memory of my mother 
